\title{
Tehetségek Magyarországa
}

Wïrlz Csilla

https://doi.org/10.47707/Kulugvi_Szemle.2021.2.08

„Célunk, hogy társadalmi egyetértést érjüink el a jövő kulcsát jelentő legértékesebb nemzeti vagyon, a tehetség felismerését, gondozását és védelmét illetôen. A tehetség kibontakoztatásához hit, bátorság és összefogás kell, mind a tehetséges egyén, mind a társadalom részérôl. Hiszüink abban, hogy a tehetséges ember önmagát boldogabbá, a közösséget pedig gazdagabbá teszi." - olvasható a Nemzeti Tehetség Központ küldetése honlapunkon.

„Mindenki tehetséges valamiben. A feladatunk az, hogy ezt közösen megtaláljuk és fejlesszük. Fel kell ébreszteni a gyermekekben az érdeklődést, és nem szabad engedni azt, hogy kihunyjon.” Ezekkel a szavakkal nyitotta meg Novák Katalin, családokért felelős tárca nélküli miniszter asszony a 2018-ban hagyományteremtő szándékkal megrendezett Budapest Talent Summit - Budapest Tehetség Csúcstalálkozót az ott megjelent küllöldi meghívott vendégek, pedagógusok és tehetségsegítéssel foglalkozó szakemberek számára. A konferencia 2021-ben is megvalósul, ezúttal az Európa Tanács magyar elnökségének égisze alatt. Célunk, hogy az Európa Tanács tagállamai és a meghívott szakemberek megismerjék Magyarország tehetséggondozó stratégiáját, a világon egyedülálló Nemzeti Tehetség Programot és az abban elért kiemelkedő eredményeket. Úgy véljük, hogy a Budapest Talent Summit kiváló lehetőség arra, hogy Magyarország imázsát emelje és nemzetközileg is követhető, jó példával járjon elő.

Nem hagyható figyelmen kívül az a szempont, hogy a tehetség hazánk egyik legfontosabb erőforrása, amely már középtávon is értéknövelô és gazdaságélénkítő hatású. Segít bennünket abban, hogy 
versenyképesek maradjunk világviszonylatban, biztosítva a magyar gazdaság fenntartható növekedését a magyar tehetségek kiemelkedő tudásának hasznosulásával. A hazai és határon túli tehetségek felismerése és gondozása nemzetstratégiai jelentőségū.

„A kormányzati gondolkodásban a magyar jövő építése a tehetséges magyar fiatalok felkarolásánál, támogatásánál kezdődik. Kulesfontosságú, hogy a kiemelkedő teljesítményre képes fiatalokat megtaláljuk, illetve célzottan segítsük annak érdekében, hogy tehetségük kibontakozzon, hasznosuljon. Számos példa bizonyítja, hogy a jó képesség, a befektetett munka, szorgalom, idő és energia sok esetben nem elegendô, ha nincs megfelelő támogató közegezért állunk a tehetséges fiatalok mögött. Tehetséggel rendelkezni nagy előny, de egyben felelősség is. Ez nem csupán egy személyes ügy, hanem nagyon fontos közösségi ügy is, minden egyes kiemelt képességú fiatal felfedezése egy újabb erőforrás, egy újabb lehetőség a magyar nemzet, a jövő generációi számára. A Nemzeti Tehetség Program (NTP) legfőbb célkitűzése a magyar tehetségek felkutatása és tehetségüik kibontakoztatásának elősegítése. A Program elfogadásával az Országgyủlés 2008 és 2028 között húsz évre kiemelt lehetőséget ad a tehetségsegítés fejlesztésére, amely a tehetséggel megáldott fiatalok hosszú távú, folyamatos és tervezhető segítését, támogatását teszi lehetővé." - olvasható Novák Katalin miniszter asszony köszöntője a Nemzeti Tehetség Program honlapján.

Kiemelt jelentôségű az, hogy ma Magyarországon létezik egy olyan program, amely milliárdos nagyságrendben segíti a tehetségek kibontakozását, azaz sok fiatal számára sorsfordító lehetőséget nyújt.

Ahogyan a Magyar Kormány számára nemzeti ügy a tehetségek és családok támogatása, a magyar emberek számára is az, hiszen adóforintjaikkal, adójuk 1\%-ának felajánlásával támogatják a Nemzeti Tehetség Programot. Magyarország Kormánya minden évben az így összegyúlt személyi jövedelemadó felajánlásokat kormányzati költségvetési forrással egészíti ki oly módon, hogy minél több 


\section{Külïgyi Szemle}

adófelajánlás érkezik be, annál nagyobb a kiegészítés összege is. 2021-ben Magyarország Kormánya támogatásával közel 3,6 milliárd forintból gazdálkodhat a Nemzeti Tehetség Program.

Évente több mint 300 ezer tehetséges hazai, vagy külhoni magyar fiatal támogatására van így lehetôség közvetett vagy közvetlen módon, valamennyi tehetségterületen, az óvodás kortól a fiatal felnőtt korig. 2009 és 2020 között több mint 15000 projekt valósult meg, a megítélt támogatások összege meghaladja a 24 milliárd forintot. A Nemzeti Tehetség Program ebből az összegből biztosítja az egyenlő hozzáférés lehetőségét is, a Program keretében célzott pályázatok segítik a hátrányos helyzetú és halmozottan hátrányos helyzetű, roma vagy fogyatékossággal élő fiatalok tehetséggondozását.

A pályázati felhívások kedvezményezettjei nemcsak maguk a tehetségek, hanem a tehetséges gyermekek szülei, a család és a pedagógusok is. A pályázatok a küilönböző tehetségterületeken megvalósuló - matematikai, természettudományos, sport és múvészeti - tehetséggondozó programokhoz nyújtanak támogatást, emellett kiemelt hangsúlyt fektetnek a digitális kompetenciák elmélyítését szolgáló, élmény- és felfedezésközpontú programok támogatására. Tavaly is volt és az idén is lesz újitásra ösztönző, a kiemelkedően tehetséges fiatalok példaértékû innovációinak támogatását célzó pályázati konstrukció. Kiemelt szempont, hogy nemesak a hazai, hanem a Kárpát-medencei szervezésủ hagyományos és online tanulmányi, továbbá művészeti versenyek szintén támogatásban részesülhetnek.

A népszerű Nemzet Fiatal Tehetségeiért Ösztöndíjra a 8-35 éves korosztály pályázhatott a tavalyi évben. Az akár egymillió forintos támogatással a hazai és határon túli, kivételesen tehetséges fiatalok kaphattak esélyt tehetségük kibontakoztatására.

A 2019. október 1-jén - elődszervezetéből kiválással - létrejött Nemzeti Tehetség Központ szakmai felügyeletét Novák Katalin miniszter asszony látja el, azaz ily módon mint állami tulajdonú nonprofit korlátolt felelősségű társaság, a Miniszterelnökség egyik háttérintézménye. Elsődleges feladata - a fiatal tehetségek felismerésének segítése 
és a tehetségek gondozása - mellett közösségépítỏ és mentortevékenységet is folytat, valamint kutatásokat végez, képzési és szakmai programokat valósít meg, továbbá egyfajta módszertani központként is múködik. Tevékenységének jelentős részét hazai és nemzetközi finanszírozású projektek keretében végzi. A központ munkájával eddig több tízezer fiatal tehetség találkozott, számos képzést, programot valósított meg mind a tehetségek, mind az őket támogató szakemberek részére. Az NTK létrehozta az ún. Minősített Tehetséggondozó Mủhelyek (MTM) hálózatát is, amelyből az országban 39 működik.

A Nemzeti Tehetség Központ célja tehetségbarát társadalmi kör nyezet kialakítása; a tehetségek segítése olyan közös, össznemzeti ügy, amely egyrészt közösségeket teremt, másrészt a társadalom tagjait összefogásra ösztönzi. Magyarország igen szerencsés helyzetben van, hiszen nagyon sok tehetséget tudhat magáénak, gondoljunk csak a magyar Nobel-díjasokra. Annak érdekében, hogy ezt a tradíciót megtartsuk, sőt tovább is vigyük, elengedhetetlen, hogy a „tehetségek Magyarországa” maradjunk.

A Nemzeti Tehetség Központ egyik zászlóshajója az első alkalommal tavaly meghirdetett Stipendium Peregrinum Ösztöndíjprogram. Célja azoknak a kiemelkedő tehetségủ magyar fiataloknak az anyagi és szakmai támogatása, akik a világ legrangosabb külföldi egyetemein terveznek továbbtanulni, illetve már felvételt is nyertek. Nemcsak a felvételi eljárás költségét és a nyelvvizsgadíjat vállaljuk át, hanem akár a tandíjat, a tanév alatt a küllföldi lakhatást, illetve a kint tartózkodás valamennyi költségét is. A támogatásért cserébe azt várjuk tőlük, hogy idővel hazatérjenek Magyarországra, és a kint megszerzett tudásukat itthon kamatoztassák.

A peregrináció, vagyis a vándordiákok külföldi egyetemjárása sok évszázados hagyomány a magyar oktatási rendszerben. Az okok és "hozadékok" alig változtak az évszázadok alatt, inkább talán csak felerősödtek: fontos azt kiemelni, hogy a fiatalok külföldi tanulása több szempontból is hasznos, mert a legrangosabb egyetemeken különleges tudásra, tapasztalatra, emellett nagyfokú önállóságra, valamint magas szintű nyelvismeretre tesznek szert. A tanulmányaik során 


\section{Külïgyi Szemle}

kialakított szakmai kapcsolati háló komoly hozzáadott értéket, sőt bizonyos esetekben innovációs tőkét is jelenthet Magyarországnak. Lehetnek olyan megpályázott szakterületek, ahol magasabb szintú tudományos kutatás zajlik, mint ma Magyarországon. Ha van olyan magyar fiatal, aki ilyen képzés részese lehet, az összességében a magyar tudást és tapasztalatot is növelni fogja.

Maga a feladat hozza létre a tehetséget: a tehetség kibontakoztatásában meghatározó, hogy minél változatosabb helyzetekben tehessék próbára magukat a fiatalok, így a környezeti kontextus, a szakmai-módszertani klíma, amelyet egy másik ország tud biztosítani, már önmagában is inspiratív erôvel bírhat.

Külföldi egyetemek előnyeként fogalmazható meg az eszközfelszereltség, a tanulási lehetőségek sokszínúsége, a korszerū képzési módszerek. Az inkluzív közegben ily módon megsokszorozódnak a szakmai impulzusok. A külföldön szerzett tapasztalatok, és a világ legrangosabb egyetemeinek eredményessége már rövid távon is pozitív hatással van a hazai oktatásra, ahol ezáltal új keretekben, tágabb perspektívában szerveződhet a tudományos élet, változatos kibontakozási lehetőségeket kínálva a fiataloknak.

A hazai munkaerőpiacon, mint mindenütt másutt, óriási jelentő séggel bír a világ legrangosabb egyetemein szerzett diplomával elhe lyezkedők aránya, a külföldön megszerzett tudás hazai hasznosulása. Különösen igaz ez azon küllöldi diplomákra, amelyek a leggyorsabban fejlődő iparágakban hasznosítható tudást jelentik. A magyar kormányzat célmondatához kapcsolódva: a legkiemelkedóbb tehetségek kimagasló támogatást érdemelnek. Ezt nyújtja a Stipendium Peregrinum Ösztöndíjprogram, amelynek két komponense van: az ún. „A komponens” a felvételi vizsgákon való részvételt, míg a „B komponens” a sikeres felvételit követően a tanulmányi év teljes körủ finanszírozását biztosítja (tandíj, megélhetési költségek, tankönyvek stb.).

A 2020/2021-es tanévre 144-en pályáztak, akik közül 17 te hetséges fiatal kezdhette meg külföldi tanulmányait. A nyertesek által megpályázott összeg összesen $168491089 \mathrm{Ft}$ volt, ezen belül a legalacsonyabb megpályázott összeg $4340000 \mathrm{Ft}$, 
míg a legmagasabb 22267620 Ft volt. Az ország minden tájáról, de még a határon túlról is kerülttek ki győztesek, egészen pontosan a következő városokból: Biatorbágy, Boca Raton (USA), Budaörs, Budapest, Debrecen, Dunakeszi, Gyöngyös, Martonvásár, Miskolc, Nagyvázsony, Pócsmegyer, Sopron, Szeged, Szentendre.

A megpályázott egyetemek számában egyértelműen az Egyesült Királyság dominált, és a nyertesek is ideje pályáztak a legtöbben: az Egyesült Királyságba 14 fő, míg Hollandiába, Svájcba és az Amerikai Egyesült Államokba 1-1 fő. Kiemelkedő volt a ter mészettudományos és műszaki szakokra jelentkezők száma. A „B” komponens nyertesei közül, ketten az "A” komponens nyer tesei is voltak, amely szintén a program népszerúségét és komplexitását mutatja.

Természetesen idén is folytatódik a Stipendium Peregrinum ösztöndíjprogram, izgatottan várjuk, hogy a 2021/2022-es tanévre ezúttal hányan jelentkeznek.

A Nemzeti Tehetség Központ külföldön is összefogja, sze mélyes és szakmai fejlődésükben támogatja, segíti a magyar diákokat, teszi ezt saját kihelyezett irodája, a Londoni Tehet ség Központon (New Generation Center) keresztül, amely szintén a Nemzeti Tehetség Program keretében jött létre 2016 ja nuárjában.

A központ alapvetỏ célja az Egyesült Királyságban és a Magyar országon élő fiatal tehetségek közötti kapcsolat kiépítése, tudásuk bővítése, tehetségük kibontakoztatásának elősegítése különféle szakmai, közösségi és kompetenciafejlesztő programokon keresztül, hiszen fontos, hogy a kint élő magyar fiatalok értesül jenek az Egyesült Királyságban és a Magyarországon induló vagy múködő magyar vonatkozású, legfrissebb szakmai lehetőségekről, kutatásokról, projektekről, mentorprogramokról.

Indulása óta két fỏ célcsoportra fókuszál a központ: az Egye süilt Királyságban tanuló, graduális, posztgraduális, vagy kutatói részprogramokban/képzésekben részt vevő, valamint az itt dol gozó 18-35 év közötti, tehetséges magyar fiatalokra. A központ 


\section{Külïgyi Szemle}

Londonban mára már egy élő, aktív közösséget múködtet, amely nek segítségével a kint élő fiatalok magyar közegben inspirá lódhatnak, tölthetik el szabadidejüket. A közösségépítésen túl kiemelt cél volt egy olyan támogató modell kidolgozása, amely éveken át képes az Egyesült Királyságban és Magyarországon élő, tehetséges fiatalokat szolgáltatásokkal segíteni. Az iroda angliai és magyarországi programjain keresztül lehetőséget teremt a szakmai kapcsolattartásra, valamint az Egyesült Király ságban élő fiatalok bekapcsolódhatnak az itthoni szakmai életbe is. Emellett a központ azokra a kint élő fiatalokra is odafigyel, akik Magyarországon kaptak képesítést, de eddig még nem volt lehetőségük a szakterüiletükön elhelyezkedni. A Londoni Tehetség Központ amellett, hogy elsősorban a fiatalok támogatására fókuszál, a pályaválasztás előtt állók segítésével, illetve azon fiatal szakemberek támogatásával is foglalkozik, akik elérkeztek karrierjük következő mérföldkövéhez, és szeretnének magabiz tosan haladni előre. A Londoni Tehetség Központ azért is egyedülálló a maga nemében, mert programportfólióját maximálisan a célcsoporthoz igazítja, azaz a programok széles körét biztosítja a fiataloknak. Fennállása óta három olyan tevékenységi kört határozott meg, amely segíti a fenti célok megvalósulását: tehet ségfejlesztő szolgáltatásokat biztosít, tehetségeknek szóló bemutatkozási lehetőségeket nyújt, valamint hazai és nemzetközi szakmai múhelyeket, fórumokat, konferenciákat rendez.

Az elmúlt 5 év alatt 213 szakmai program valósult meg, 30 526 személyt értek el a képzéseiken és rendezvényeiken keresztül, bevonva több mint 95 támogató partnert, és kialakítva ezzel egy stabil, sokrétú és egyre bővülő szakmai kapcsolatrendszert az Egyesült Királyságban és Magyarországon. A külföldön élő fiatalok számára nyújtott közvetlen lehetőségek közül kiemelke dik a 2017-ben indult NEXT Hungary Gyakornoki és Pályakezdỏ Program, amelynek alapvető célja, hogy az Egyesült Királyságban tanuló vagy frissen végzett hallgatóknak nyári szakmai, illetve pályakezdő pozíciókat ajánljon magyarországi vezető cégeknél. 
A NEXT Hungary Program további érdeme a munkaerőpiaci attitűdök formálásában rejlik. A munkáltatók, akik eddig azt gondolták, hogy a külföldön tanuló fiatalok nem szándékoznak Magyarországon dolgozni, felismerték ennek az álláspontnak a vitathatóságát. A program egyedülálló hozzáférést biztosít a vállalatoknak egy számukra rendkívuil értékes, ám kevésbé elérhetô célcsoporthoz. Ezen túlmenően ebben az évben elindítottuk a "NEXT Ambassador” programot is, amelynek kiemelt feladata a Londoni Tehetség Központ és a Nemzeti Tehetség Központ munkájának népszerúsítése a célközönség részére.

A NEXT Hungary indulása óta számos személyes találkozó ke rült megszervezésre Magyarországon a munkáltatók és a fiatalok között. A hallgatók kérésének megfelelően a programban több karrierworkshop megvalósítása is kiemelt szerepet kapott. A tehet ségfejlesztő szolgáltatások keretein belüil olyan programok is helyet kapnak, mint a vállalkozói kompetenciafejlesztő workshopok.

A Londoni Tehetség Központ másik kiemelt programeleme a nyilvános beszéd képzés. Itt a cél az, hogy az Egyesült Királyságban élő magyar fiatalok olyan angol nyelvű kurzuson vegyenek részt, amely segíti őket abban, hogy jobban kifejezhessék magukat. Bármilyen kommunikációs szituációba kerülnek, legyen az egy egyetemi vagy munkahelyi prezentáció, egy konferencián való felszólalás vagy éppen egy önálló előadás nagyobb közönség előtt, megfelelően tudják kifejezni magukat, magabiztosan tudják mondanivalójukat előadni. A tréning jól illeszkedik a projekt tehetségfejlesztô szolgáltatáscsomagjába, hiszen a 21. század elengedhetetlen követelménye, hogy jól és célirányosan kommunikáljunk. A jelenlegi munkaadók, egyetemi programok keresik azokat a fiatalokat, akik megfelelően tudják magukat kifejezni, és nem félnek a közönség előtti szerepléstől sem.

A mentorálás mindig is nagy hangsúlyt kapott a Londoni Tehetség Központnál. A mentorprogram 2019 tavaszán indult el. A cél az volt, hogy az Egyesült Királyságban tanulmányokat folytató hallgatókat olyan személyes tanácsadással lássuk el, amely a késóbbiekben, 


\section{Külïgyi Szemle}

az egyetem befejezése után elősegíti, hogy Magyarországon foly tathassák szakmai karrierjük építését. A mentorprogramban az Egyesült Királyságban tanuló magyar hallgatókat összekötjüik a Magyarországon élő sikeres vállalatvezetőkkel, menedzserekkel, a különböző szakterületek kiemelkedő példaképeivel, akik küiföldi tanulmányaik vagy hosszabb-rövidebb külföldi munkavállalásuk után Magyarországot választották (újra) karrierépítésük terepéül. A mentorprogramba olyan Magyarországon élő fiatal közép- és felsővezetőket kérünk fel mentornak, akik szívesen vállalják, hogy egy-egy külföldön tanuló magyar fiatallal havonta egyszer online csatornán beszélgetnek, és jó tanácsokkal látják el őket. A mentorálás meghatározott témák alapján halad, de a beszélgetés folyamán a mentor és mentorált szabadon választhat témakört.

Egy másik, már 2016 óta működő sikeres rendezvény, ami a szakmai fejlődés mellett közösségi szereppel is bír, a Talent Zone elnevezésú nyári lábor, amelynek a keretein belül külföldön, Magyarországon és Erdélyben tanuló magyar fiatalok dolgoznak egy Magyarországot érintő probléma megoldásán csoportos formá ban. Az elmúlt években ilyen megoldást igénylő téma volt például egy közösségi ház épitése Budapesten, vagy a Tisza-tó turisztikai lehetőségeinek fejlesztése Poroszlón. A Talent Zone nagy sikerủ rendezvény, ahogyan az egyik résztvevő írta: "Minden évben nagyon várom. Azért is, mert egy olyan fontos, kreatív projekten dolgozhatok hozzám hasonló fiatalokkal, ami segít megoldani egy aktuális társadalmi problémát, és eközben fejleszti a problémamegoldó és csapatmunka-készségeimet, de azért is, mert mindeközben rengeteg új barátra tehetek szert, és megismerhe tem Magyarországot. Máig tartom a kapcsolatot a Talent Zone on megismert barátaimmal, rendszeresen beszélünk és örülüink egymás sikereinek, amelyhez ez a nyári tábor is hozzájárult."

A Nemzeti Tehetség Központ munkája során a tehetségeken kívül a velük foglalkozó szakemberekre, pedagógusokra is jelentős figyelmet fordít. Teszi ezt a tehetségekkel foglalkozó 
szakemberek és pedagógusok képzésével, szakmai munkájuk segítésével, szemléletformáló és érzékenyítő szakmai mûhelymunkával, valamint harmincórás akkreditált pedagógus-továbbképzésekkel.

Az EFOP 3.2.1 „Tehetségek Magyarországa” címû kiemelt európai uniós projekt 2016. január 4-én indult és 2021. június 30-án zárul. Ebben a nagy, többéves projektben a Nemzeti Tehetség Központ konzorciumvezető és a Magyar Tehetségsegítő Szervezetek Szövetsége (MATEHETSZ) konzorciumi partner, az összköltségvetés több mint hatmilliárd Ft. A projekt tevékenységét területileg a Közép-Magyarország régióban a Nemzeti Tehetség Program hazai finanszírozású tükörprojektjei egészítik ki.

Az európai uniós projekt, illetve tükörprojektjeinek kiemelt cél ja, hogy minden tehetséges magyar fiatal esélyt kapjon tehetsége felfedezésére, kibontakoztatására és fejlesztésére. Ennek megfelelően kialakítottuk, továbbfejlesztettük, illetve összehangoltuk a tehetségazonosításon, illetve csoportos és egyéni fejlesztésen alapuló tehetséggondozó szolgáltatások rendszerét. Tehetségméró eszközöket fejlesztettünk, szaktémákban kutatásokat folytattunk, valamint pedagógus-továbbképzéseket fejlesztettünk és szerveztünk, továbbá létrehoztuk a Minősített Tehetséggondozó Műhelyek hálózatát.

A Minósített Tehetséggondozó Múhelyek (MTM) olyan nevelésioktatási mintaintézmények, amelyek a kiemelten tehetséges fiatalokra irányuló tehetséggondozó, tehetségfejlesztő tevékenységet végeznek, a tehetséggondozásban részt vevô pedagógusok és szakemberek számára tehetségszakmai támogatást és szolgáltatást nyújtanak, valamint egymással szakmai hálózatot alkotnak, mindezt meghatározott köz igazgatási területi egységekhez kapcsolódó körzetben végzik.

A hazánk területén egyenletes lefedettséget biztosító MTM hálózatot 39 intézmény alkotja (a konvergenciarégiókban 31, a közép magyarországi régióban 8). Az MTM cím öt évre adományozható.

A 4 budapesti, 4 pest megyei, 6 dél-alföldi, 7 észak-alföldi, 4 nyugat dunántúli, 4 közép-dunántúli, 5 dél-dunántúli, 5 észak-magyarországi múhely nagy részét a tankerületek tartják fent, emellett felsőoktatási intézmények gyakorlóiskolái, egyházi, alapítványi és vállalati 


\section{Külïgyi Szemle}

fenntartású iskolák büszkélkedhetnek az MTM címmel. Az MTM hálózat feladata, hogy az egyes intézmények keretein belül mód szertanilag megalapozott tehetségszűrést, tehetségazonosítást végezzen, illetve minden tehetséges tanuló számára az igényeinek és a képességeinek legmegfelelőbb tehetséggondozó, -fejlesztő programokat kínáljon, illetve közvetítsen, továbbá, hogy környezetében szakmai tanácsadást, konzultációt biztosítson a szülők, a pedagó gusok, valamint a tehetségekkel foglalkozó szakemberek, intézmé nyek számára. A tehetségekkel történő foglalkozás teljes folyama tát - az általános képességeken túl - lehetőség szerint kiterjesztik a gardneri képességterületek mindegyikére, továbbá a speciális helyzetû tehetségesoportokra és foglalkozási területekre.

Az MTM-hálózat legtehetségesebb tanulói minden évben egyéni ösztöndíjra pályázhatnak, melynek célja az egyéni tehet ségterületeken kiemelkedő teljesítményt nyújtó tanulók támo gatása. Az elmúlt két évben 277 tanuló részesült összesen több mint 35 millió forint vissza nem térítendő támogatásban or szágos szinten a Nemzeti Tehetség Központ és a MATEHETSZ együttes finanszírozásával.

A Nemzeti Tehetség Központ - a felsorolt célok elérése ér dekében - komplex támogatási csomagokkal és programokkal tá mogatja a címbirtokos intézményeket, mint például ingyenes akkreditált pedagógus-továbbképzések, tehetséges tanulókat támogató mentorprogramok, képesség- és tehetségfejlesztő eszközök, szüilőket és szakembereket bevonó szakmai rendezvények, az MTM-ek szakembereinek nyújtott folyamattanácsadás, szupervízió, a szakmai együttmúködések támogatása.

A Nemzeti Tehetség Központ különös hangsúlyt fektet az iskolák igényeinek legjobban megfelelő, korszerű, tehetségfejlesztést támogató eszközök biztosítására. A korábbi időszakban az MTM-ek projektorokat, tableteket, és laptopokat kaptak elsősorban a tehet séggondozó pedagógusok munkájának közvetlen támogatása cél jából. 2020-ban kifejezetten a specifikus tehetségfejlesztő programokhoz, szakkörökhöz, műhelyekhez nélkülözhetetlen eszközök 
beszerzése történt meg. Az eszközök sokfélesége tükrözi az MTMek rendkívïl gazdag és szerteágazó tehetséggondozó tevékenységeit, amelyek az iskolai kísérletektől és a robotikai eszközöktől a ter mészettudományos szemléltető eszközökön keresztül a különböző fejlesztő társasjátékokig és hangszerekig terjedtek.

A továbbképzések hozzájárulnak a pedagógusok tehetségfel ismerő, -gondozó szakmai tudásának gyarapodásához. Az „Iskolai tehetségazonosítás online eszközökkel” képzés célja, hogy a részt vevők megismerjék a tehetségazonosítás kihívásait, elsajátítsák a tehetségek felismerését támogató, a tanulási szokásokhoz jól illeszkedő online mérőeszközök alkalmazását. Gyakorlatot szereznek az online mérés lebonyolításában, az eredmények értelmezésében, a hozzá kapcsolódó fejlesztőprogramok meghatározásában. Képessé válnak az intézményük önpozicionálására az országos tehetséghálózatban, valamint a regionális kapcsolódási pontok meghatározására.

A „Tehelség-porlfólió: A tanulói portfólió felhasználási lehetóségei a tehetséggondozás folyamatában" képzés rálátást nyújt a tanulói portfólió készítésének lehetôségeire. A képzés keretében a résztvevők megismerik a portfólió alkalmazásának alapelveit és értékelési szempontjait, a tanulói reflexiók ösztönzésének, értékelésének és a pedagógusi reflexiók megfogalmazásának módszereit, valamint a tehetséggondozásban már működő jó gyakorlatokat.

A „Tehetségtámogató tanulásszervezés” címû folyamatba ágyazott továbbképzés célja, hogy a résztvevők megismerjék a tehetségbarát osztálytermi gyakorlat alapelveit és legfontosabb módszereit. Ezáltal képessé válnak kreatív, nyitott és elfogadó osztálytermi légkört teremteni, változatos módszereket alkalmazni, és a tehetségesek számára egyedi fejlesztőprogramot kidolgozni.

A „Komplex tehetségtámogatás az iskolában” című képzés célja a pedagógusok felkészítése a tehetséggondozás komplex folyamatára, valamint, hogy elsajátítsák a tehetséges és a tehetséges 


\section{Külïgyi Szemle}

alulteljesítő tanulók jellemzôinek felismerését támogató mód szereket, azok szakszerű alkalmazását. Megismerik a tehetség programok különféle elemeit és azok megválasztásának szem pontjait, az iskolai tehetségfelismerést érintő döntéshozatal folyamatát és eredményes kommunikációját.

A továbbképzések mellett szakmai múhelymunkákat is kínálunk, amely során szemléletformálás, az intézményi tehetséggondozó munka strukturáltabbá válása, új szakmai koncepciók kidolgozása valósul meg. Eddig 3000 pedagógus és támogató szakember vett részt a képzéseinken.

A Nemzeti Tehetség Központ online tudásbázist is létreho zott, ahol az intézményi tehetséggondozó munkára vonatko zó ajánlások, naprakész információk kerülnek megjelenítésre, amely a pedagógusok közötti tapasztalat- és tudásmegosztást segíti elö.

Meggyőződésünk, és egyes kutatásaink is ezt támasztják alá, hogy a tehetséggondozás kulcsszereplői, akiken a legtöbb múlik, azok a szülők mellett a pedagógusok. Lehet bármilyen megalapozott egy-egy szakmai program, lehet bármennyire is kidolgozott egy jó gyakorlat, a lelkesedését, szakmai tudását, idejét és energiáit beleadó tanárokon múlik, hogy mindezek sikeresen múködnek-e. Éppen ezért fontos, hogy a kiemelkedő tehetséggondozó munkát végzô pedagógusok méltó elismerésben része süljenek. A „Bonis Bona - A nemzet tehetségeiért” díjra olyan, a tehetséggondozásban kiemelkedő munkát végző magyarországi és határon túli magyar vagy magyarországi nemzetiségi köznevelési intézményben dolgozó pedagógusok, gyógypedagógusok, szakoktatók, felsőoktatásban dolgozó oktatók, civil szervezetek tehetségsegítői és a tehetséggondozás területén működő szervezetek jelölhetők, akik oktatják, nevelik, segítik a gyermekeket, tanulókat, fiatal tehetségeket. A díj egyszerre szakmai elismerés, hiszen kollégák, tanítványok és szakmai bizottságok ítélik oda, ugyanakkor társadalmi elismerés is, hiszen 3 kategória esetében a jelölés nyílt bárki számára. A díj öt kategóriában kerüil átadásra. 
Az egyes kategóriák:
A: kiváló tehetséggondozó
B: kiváló tehetségfejlesztő
C: kiváló tehetségtámogató
D: kiváló tehetséggondozó szervezetE. életműdíj

A „Bonis Bona - A nemzet tehetségeiért” díj mellett 2018-ban létrehozták a „Tehetségbarát Önkormányzat” díjat is, amelynek célja, hogy elismerésben részesüiljenek azon helyi önkormányzatok, amelyek kiemelkedő módon járulnak hozzá a tehetséges fiatalok felkutatásához, támogatásához, példamutató együittmúködést folytatva tehetséggondozó szervezetekkel.

A tavalyi évben összesen 64 díj került átadásra a tehetséggondo zásban kiemelkedő munkát végző hazai és határon túli pedagógusok és tehetségsegítő szakemberek számára. A díjazottak között 57 szak ember, 1 tehetséggondozó szervezet, illetve 6 önkormányzat volt. A 2013-ban alapított, „Bonis Bona - A Nemzet Tehetségeiért” díjat eddig összesen több mint 900 pedagógus vehette át. Az elismerés forrását 2020-ban is a Nemzeti Tehetség Program (NTP) biztosítot ta, a díjak odaítélésnek fő célja, hogy erkölesi és anyagi elismerésben részesítse azokat a hazai és határon túli magyar, vagy magyarországi nemzetiségi szakembereket, akik munkájuk során kiemelkedően sokat tesznek a nemzet tehetségeinek kibontakoztatásáért.

A Nemzeti Tehetség Központ másik zászlóshajó programja is egy tanárhoz, művész-tanárhoz kötődik. Snétberger Ferenc, a Snétberger Program alapítója, Kossuth- és Liszt-díjas gitármúvész, zeneszerző, az egyik legsikeresebb és leghíresebb jazz- és klasszikus zenei előadóművész. A ma Berlinben élő roma származású művész egy szegény, hétgyermekes salgótarjáni család legkisebb gyermekeként a saját tehetségére és belsổ motivációjára támaszkodva vált világhírủ gitáros sá állami segítség nélkül. A roma társadalom felzárkóztatásának elkötelezett híveként egy olyan iskolát hozott létre Felsőörsön, ahol olyan fiatalok tanulhatnak zenét, mint amilyen maga is volt egykor. 


\section{Külïgyi Szemle}

A Snétberger Program középpontjában a különleges zenei tehet séggel rendelkező, hátrányos helyzetű fiatalok tehetséggondozása áll olyan egyedi módon, amely különbözik minden más iskolarendszerú és iskolarendszeren kívüili, a többségi társadalmi oktatási, nevelési hagyományokra épülő rendszertől, ugyanakkor a két rendszert sajátos módon integrálja. Az országos szintű múködés öt terület köré szervezôdik: tehetségkutatás, zenei képzés, munkaerőpiaci képes ségfejlesztés, pályaorientáció és karriertanácsadás, szociális gon dozás, mentorálás, koncertszervezés. Folyamatosan kutatnak olyan hangszeren játszó gyerekek után, akik hátrányos helyzetük miatt a képességeiktől messze elmaradó oktatásban részesülnek.

A hátrányos helyzetủ, többségében roma származású fiatalok Magyarország minden tájáról, a határon túli magyar lakta területekről is érkeznek Felsőörsre. A meghallgatásokon Snétberger Ferenc választja ki a legtehetségesebb jelentkezőket. A zenei előképzettség, a kottaolvasás, a saját hangszer nem feltétel, csak a tehetség számít. Erre a veleszületett adottságra alapozva a fiatalok egy olyan komplex képzésben részesülnek, amely nagyban elősegíti zenei előmenetelük mellett a társadalomba való beilleszkedésüiket is. A felsőörsi központ mind infrastruktúrájában, mind elhelyezkedésében az elmélyült zenei képzésre lett kialakítva, itt minden a zenéről szól. A fókuszban az egyéni képességekhez mért folyamatos fejlődés áll, amelyet egy egyedülálló közösségben valósítanak meg, hiszen a különböző korú és képességű diákok a kurzusok alatt együtt élnek Felsőörsön a tanáraikkal, mentoraikkal és a stáb tagjaival.

Minden évben 60, zeneileg különösen tehetséges, hátrányos helyzetú, 10 és 22 év közötti, főként roma származású fiatal kap lehetőséget, hogy ebben az intenzív zenei képzésben részt vegyen, ahol ezen túlmenően személyre szabott készségfejlesztést, külön órákat, vizsgafelkészítést és pályaorientációs tanácsadást kapnak. Az elfogadáson alapuló, tudásfókuszú szemlélet a központ életének minden mozzanatát áthatja. Snétberger Ferenc a legjobb klasszikus és jazz mûvészek meghívásával választja ki tanárait. A tanári karban éppúgy, mint a stáb többi tagja között, roma és nem roma kollégák 
dolgoznak együtt. A kurzusok szüneteiben a diák, a központ, a család és az iskola között a mentor az összekötő, akihez a diák bizalommal fordulhat.

A nyári kurzussal indul az évfolyam, amely hat hétig tart a nyári szünetben. A három-három hetes ôszi és tavaszi kurzus az iskolai szünetek köré szerveződik. Az őszi és a tavaszi kurzus között hoszszabb idő telik el, így a mentori tevékenység ebben az időszakban kulcsfontosságú. Kiemelt hangsúlyt kap a diákok tanulmányi előmenetelének, valamint a konzervatóriumba, zenei felsőoktatási intézménybe történő felvételük követése és támogatása. A családlátogatás fontos eleme a programnak, mert a családok támogató hozzáállása, a programmal járó előnyök és terhek tisztázása elengedhetetlen a jó partneri kapcsolathoz és a diákok közös támogatásához. A kurzusok alatt minden diák egyéni órarendet kap, amelyben az alábbi órákat biztosítja a központ: egyéni fơtárgy (hangszeres - jazz és klasszikus) órák, kamara órák (klasszikus), zenekari órák (jazz + klasszikus), ritmusgyakorlat, zeneszerzés, dobok bőrözése, klasszikus zeneelmélet, jazzelmélet, Jazz-Bach improvizáció, klasszikus zenetörténet, jazztörténet, kamarazene módszertan (klasszikus), angol nyelv, Alexandermódszer (egyéni), Kovács-módszer (csoportos), elmélet a gyakorlatban, ritmusszekció, alaphang (reggeli mozgás hetente kétszer), visszhang (csoportos beszélgetések), mentorórák, pályaorientáció, rekreációs és kulturális programok, valamint a meghívott előadók workshopjai.

A résztvevők minden kurzus után kurzusértékelést tartanak minőségbiztosítási céllal. Ez ideális alkalom a jó gyakorlatok együittes meghatározására és a következtetések levonására, hogy mindinkább hatékonyan működjön a program. A folyamatos monitorozás elengedhetetlen a csoportkohézió megtartása és céltudatos hasznosítása érdekében. A felsőörsi központban a kurzusok alatt nyílt napokat szerveznek, ahol bárki betekinthet az ott folyó szakmai munkába.

A program sikeressége egyre jobban mérhető a diákok eredményein keresztül. Míg a szociális téren való fejlődés nem feltétlenüil kézzelfogható, az iskolai előmenetel, a különböző díjak és ösztöndíjak 


\section{Külïgyi Szemle}

elnyerése, az egyre több sikeres koncert számokban mérhető. Évről évre egyre több diák jut be konzervatóriumba vagy zenei felsőoktatási intézménybe Magyarországon és küllföldön egyaránt. A határon túli magyar lakta területekrôl érkező diákok esetében kiemelten fontos az ilyen irányú esélyteremtés. A 2017-es év kiemelkedő eredményeket hozott, hiszen egy középiskolás diák sikeres felvételi vizsgát tett a Liszt Ferenc Zenemûvészeti Egyetem Különleges Tehetségek osztályába, míg másik három diák első egyetemi évét kezdhette meg ugyanitt, egy negyediket pedig ösztöndíjjal vettek fel a berni Múvészeti Egyetemre. Azóta egy másik diák már a Hágai Királyi Konzervatórium hallgatója.

A Snétberger Program diákjai rendszeresen vesznek részt versenyeken is. A legfontosabb eredmények: 2016 - Vysledky Jazz Fesztivál (első díj), Cziffra György zongoraverseny (küilöndíj); 2017 - Belvárosi Jazz Verseny (8 különdíjas diák), Országos Richter János klarinétverseny (első díj); 2018 - Sibelius Nemzetközi Hangszerverseny, Finnország (első díj); 2019 - Jazz START Up, Szlovákia (fődíj), Beyerdynamic, Szlovákia (küiöndíj), Nemzetközi gitárverseny, Szerbia (első helyezés), Országos Zongoraverseny (küilöndíj). Ezen túlmenően minden évben 2-3 diák nyer egyhónapos tanulmányi utat Berlinbe a Collegium Hungaricum támogatásával. Az Inkubátor Program keretein belül a diákok betekintést nyerhetnek a berlini zenei életbe.

A diákok rendszeresen fellépnek, kb. százórányi koncertet adnak évente, a legnagyobb és a legnívósabb magyar hangversenytermekben, fesztiválokon. Ez nemesak azért fontos a diákok számára, mert a színpadon való szereplésben komoly gyakorlatra tehetnek így szert - sokszor neves múvészekkel együtt - hanem azért is, mert bemutathatják tudásukat, és emellett hiteles módon képviselhetik a program mottóját, hogy „a zene felemel”. A kurzusokat zárókoncerttel fejezik be. Ezeken az alkalmakon a diákok, a meghívott vendégek, a szülők és családok, a stáb tagjai és az érdeklődők közösen ünnepelnek.

Snétberger Ferenc célja, hogy a program egyedülálló módszerta nát bemutassa mind szélesebb körben nemzetközi szinten is. Így a diákok játszottak már többször Berlinben, Londonban, továbbá Izraelben, 
Ausztriában, Norvégiában, Szlovákiában, Bulgáriában és Olaszországban is. 2017-ben a Brüsszelben megrendezett Roma Platformon több mint 250 magasrangú politikus, európai intézmények és nemzetközi szervezetek képviselői, roma és pro-roma szervezetek, valamint az akadémia területéről érkező résztvevők számára adott áttekintést a Központ múködéséról és komplex programjáról Snétberger Ferenc, a diákok pedig koncerttel bizonyították a módszer sikerességét.

2019-ben a Yehudi Menuhin Alapítvány meghívására adtak több koncertet Madridban a Nemzetközi Roma Nap alkalmából. A Spanyol Roma Kulturális Intézet a Nuevos Creadores díjjal méltatta tevékenységüket. A spanyol királyi család tagjai, többek között Zsófia királyné és Iréne fơhercegnő is elismerését fejezte ki a magas színvonalú koncertért és a központban folyó munkáért. Ugyanebben az időszakban léptek fel Portugáliában a Terras sem Sombra fesztiválon. Strasbourgban az Európa Tanács melletti magyar állandó képviselet meghívásá ra játszottak az ottani Pavillon Joséphine-ben, a washingtoni nagy követség révén a Ronald Reagan Centerben, valamint a stockholmi nagykövetség révén az Eric Ericsonhallenben.

Az eddigi tapasztalatok azt bizonyítják, hogy a Snétberger Program egyedülálló Európában. Sikeres munkájukat számos díjjal is elismer ték már, mint például: 2012 - „SozialMarie” társadalmi innovációs díj; 2013 - Emberi Erőforrások Minisztere Miniszteri Elismerỏ Oklevél; 2014 - UniCredit közönségdíj és SAP digitális innovációs díj; 2015 Millenium-dij (Szellemi Tulajdon Nemzeti Hivatala); 2016 - Tehetségpont akkreditáció; 2018 - Bonis Bona - A nemzet tehetségeiért díj, Ki váló tehetséggondozó szervezet kategória; 2019 - Magyar Örökség díj.

Zárszóként fontos kiemelni, hogy a Nemzeti Tehetség Központ Novák Katalin miniszter asszonynak köszönhetően tevékenységéhez minden szüikséges kormányzati támogatást, eszközrendszert megkap annak érdekében, hogy tovább tudjon építkezni és folytatni tudja a megkezdett munkát. Miniszter Asszony szavait idézve: „Hiszem, hogy a tehetséggondozás összetett világát együtt tudjuk csak feltérképezni, ahogyan együtt tehetjük a legtöbbet a tehetséges magyar fiatalok támogatásáért is." 